\title{
Insights into the Roles of Prebiotics and Probiotics in the Large Intestine
}

\author{
Su Jin $\mathrm{An}^{1}$, Jae Yeong $\mathrm{Kim}^{1}$, In Soon $\mathrm{Choi}^{2}{ }^{2}$ and Kwang Keun Cho ${ }^{1}$ \\ ${ }^{1}$ Department of Animal Resources Techndogy, Gyeongnam National University of Science and Technology, Jinju 660-758, Korea \\ ${ }^{2}$ Department of Biological Science, Silla University, Busan 617-736, Korea
}

Received October 8, 2013 /Revised October 10, 2013 /Accepted October 20, 2013

\begin{abstract}
According to facts revealed up until the present, there are a total of 68 known phyla on earth, including 55 phyla of bacteria and 13 phyla of archaea. The human large intestine has 9 phyla of microorganisms, which is a relatively lower diversity compared to the general environments of soil or sea. The diversity of intestinal microorganisms is affected by the characteristics of the host (genetic background, sex, age, immune system, and gut motility), the diet (non-digestible carbohydrates, fat, prebiotics, probiotics), and the intake of antibiotics, which in turn have an effect on energy storage processes, gene expressions, and even metabolic diseases like obesity. Probiotics are referred to as living microorganisms that improve the intestinal microbiota and contribute to the health of the host; in addition, probiotics usually comprise lactic acid bacteria. Recently, bacteriotherapy using probiotics has been utilized to treat sicknesses like diarrhea and irritable bowel syndrome. Prebiotics are a food ingredient which can selectively adjust intestinal microorganisms and which comprise inulin, fructooligosaccharides, galactooligosaccharides, and lactulose. In recent days, attention has been paid to the use of dietary cellulose in the large intestine and the production of short chain fatty acids (short-chain fatty acids) in relation to obesity and anticancer. More research into microorganisms in the large intestine is necessary to identify specific microorganism species, which are adjusted by diverse non-digestible carbohydrates, prebiotics, and probiotics in the large intestine and to understand the connection between sicknesses and metabolites like short chain fatty acids produced by these microorganism species.
\end{abstract}

Key words : Probiotics, prebiotics, large intestine, gut microbium, SCFA

\section{Introduction}

100 years ago, Elie Metchnikoff (a Russian scientist, Nobel laureate, and professor at the Pasteur Institute in Paris) said that intestinal autointoxication and resultant aging adjust gut microbiota or decomposes proteins, substitute proteolytic microbes such as Clostridium (which produce toxicants like phenols, indoles, and ammonia with useful microbes), and inhibit toxicity. He developed milk that is fermented by a bacterium called Bulgarian bacillus [18, 48]. Bifidobacterium is called Bacillus bifidus communis, since it was first separated from a breast-fed infant by Henry Tissier (of the

\footnotetext{
*Corresponding author (Kwang Keun Cho)

Tel : +82-55-751-3286, Fax : +82-55-751-3689

E-mail : chotwo2@gntch.ac.kr

*Co-corresponding author (In Soon Choi)

Tel : +82-51-999-5647, Fax : +82-51-999-5644

E-mail : ischoi@silla.ac.kr

This is an Open-Access article distributed under the terms of the Creative Commons Attribution Non-Commercial License (http://creativecommons.org/licenses/by-nc/3.0) which permits unrestricted non-commercial use, distribution, and reproduction in any medium, provided the original work is properly cited
}

Pasteur Institute), and the administration of bifidobacteria to children was recommended because it can substitute proteolytic bacteria, which causes diarrhea $[2,38]$

The term probiotics was defined in 1965 by Lilly and Stillwell as microbially derived factors that stimulate the growth of other microorganisms, and in 1989 Roy Fuller added significance to the definition, saying that probiotics have viability and should have a beneficial effect on the host $[2,32]$. Probiotics may be defined as a living microbe that is beneficial to the health of the host, and a substance that is turned into various products such as food, drugs, and dietary supplements to help improve intestinal microbiota in humans or animals [43, 45]. In general, such microorganisms as Lactobacillus and Bifidobacterium species are used as probiotics; the yeast Saccharomyces cerevisiae, and some E. coli and Bacillus species are used as well. Lactic acid bacteria (LAB) including the Lactobacillus species have been used for dual functions of food fermentation and health benefits for thousands of years and are widely used for fermented milk products like yoghurt [24]. L. casei was first separated from Emmental cheese and is used as an acid-producing-starter to ferment milk and add flavor to it; being a microorganism 
which is mostly used as a microorganism for manufacturing liquid yoghurt, it has an anticancer effect and it also increases IgA, an immunity ingredient on the mucous membrane of the small intestine, to strengthen immunity [35]. $L$ acidophilus was first separated in 1900 by Moro from excrement samples of a newborn baby, and then once again separated by Metchnikoff from Bulgarian yoghurts. This microorganism settles down well in the small intestine and has functions to reduce the blood cholesterol, intensify immunity, and improve constipation. It shows good resistance to bile acid and acidity and produces antimicrobial substances; therefore, it is mostly used as an industrial probiotic for milk products $[35,52]$. L. reuteri settles down well in the stomach, small intestine, large intestine, and vagina, and has better acid resistance than $L$. acidophilus; it also composes antimicrobial substances (reuterin) and strongly inhibits almost all harmful bacteria. It is useful as a probiotic for infants as well, since it has an excellent effect in improving diarrhea and intensifying immunity [35]. Bifidobacterium longum was separated from the excrement samples of men, and many researchers have found that it is a microorganism subservient to the health of men [35]. It is also widely used as a probiotic along with $L$. acidophilus since it has such merits as reducing blood cholesterol concentration, anticancer effects, and increasing immunity [24, 26]. Table 1 presents the most common probiotics such as dairy products and probiotic-fortified foods, which may be used in the form of tablets, capsules, or sachets (containing the bacteria in freezedried form). Patrizia et al. [8] conducted an experiment on 10 patients contracted with functional diarrhea or irritable bowel syndrome by using probiotics mixed with $B$. longum, L. casei, L. delbrueckisup, bulgaricus, and L. plantarum An observation was made of changes in excrement samples before the treatment, during the 20-day treatment, and 10 days after the treatment; it was found that the conditions of the patients gradually improved as the number of Bifidobacterium and Lactobacillus microorganisms increased in the intestine during the treatment when probiotics were administered. However, 10 days after the treatment, their conditions returned to those before the treatment. This demonstrates that probiotics can be used to treat specific diseases in the intestine of humans, which is a basic theory of the newly emerging 'bacteriotherapy' $[34,49]$. Another example of the therapy is that, when Streptococcus aureus is taken orally, this microorganism significantly reduces the formation of other harmful microorganisms [47]. A research into men found that probiotic strains endure in the intestine only for a short time [53]. Yet, it was also found that, once microbes inputted from the outside have successfully settled down, they would change the previous structure of microorganism colonies [27]. Such a change in the structure may have an effect on the digestion or physiology on the brush border of men. Research on mice had a very encouraging result. It was found that, when Lactobacillus paracase i was administered to mice infected with Trichinella Spiralis, they could successfully settle down and normalize their energy, fat, amino acid, and metabolism [33].

\section{Prebiotics}

Probiotics are used to directly administer living microorganisms so as to help improve intestinal microbiota, while prebiotics are a product used by useful microorganisms in the large intestine and which have a function of promoting the growth or activity of intestinal microorganisms. Prebiotics are a dietary substance which is composed of non-starch polysaccharides and oligosaccharides, most of which are not digested well by the enzymes of humans, and which can selectively promote the growth of intestinal microorganisms that are not harmful to the body but beneficial [20]. Unlike probiotics, prebiotics (which are a food ingredient) should not be digested or absorbed in the small intestine, and they selectively activate useful microorganisms such as lactobacillus and Bifidobacterium from among microorganisms in the large intestine, and inhibit germs and other harmful microbes [20]. Commonly known prebiotics include inulin, fructooligosaccharides, galactooligosaccharides, lactulose, and breast milk oligosaccharides. Lactulose is a synthetic disaccharide used as a drug to treat constipation and hepatic encephalopathy; fructooligosaccharides are naturally contained in such foods as wheat, onions, bananas, honey, garlic, and leeks, and may be separated from chicory root or composed through enzymes from sucrose. When the fructooligosaccharides are fermented in the colon, they increase the bifidobacteria number, calcium absorption, and fecal weight and shorten the gastrointestinal transit time, lowering the blood lipid levels [19, 21, 36]. Hermie et al. [23] report that, when inulin is taken, Bifidobacterium (an intestinal useful microbe) will increase and secrete IgA and mucin, which have an effect on the maintenance of intestinal functions [37]. Also, bifidobacteria ferment inulin and generate acetic acid, propionic acid, and butyric acid; acetic acid and propionic acid are used to gen- 
Table 1. Examples of probiotic strains in products [20]

\begin{tabular}{|c|c|c|}
\hline Strain (alternative designations) & Brand name & Producer \\
\hline Bifidobacterium animalis DN 173010 & Activia & Danon-e/Dannon- \\
\hline Bifidobacterium animalis subsp. lactis $\mathrm{Bb}-12$ & Chr. Hansen & \\
\hline Bifidobacterium breve Yakult & Bifiene & Yakult \\
\hline Bifidobacterium infantis 35624 & Align & Procter \& Gamble \\
\hline Bifidbbacterium lactis HN019 (DR10) & Howaru Bifido & Danisco \\
\hline Bifidobacterium longum BB536 & & $\begin{array}{l}\text { Morinaga Milk } \\
\text { Industry }\end{array}$ \\
\hline Enterococcus LAB SF 68 & Bioflorin & Cerbios-Pharma \\
\hline Escherichia coli Nissle 1917 & Mutaflor & Ardeypharm \\
\hline Lactobacillus acidophilus LA-5 & & Chr. Hansen \\
\hline Lactobacillus acidophilus NCFM & & Danisco \\
\hline Lactobacillus casei DN-114 001 & $\begin{array}{l}\text { Actimel, } \\
\text { DanActive }\end{array}$ & Danon-e/Dannon- \\
\hline Lactobacillus casei CRL431 & & Chr. Hansen \\
\hline Lactobacillus casei F19 & Cultura & Arla Foods \\
\hline Lactobacillus casei Shirota & Yakult & Yakult \\
\hline Lactobacillus johnsonii La1 (Lj1) & LC1 & Nestlé \\
\hline Lactococcus lactis L1A & Norrmejerier & \\
\hline Lactobacillus plantarum $299 \mathrm{~V}$ & $\begin{array}{l}\text { GoodBelly, } \\
\text { ProViva }\end{array}$ & NextFoods Probi \\
\hline Lactobacillus reuteri DSM 17938 & $\begin{array}{l}\text { L. reuteri } \\
\text { Protectis }\end{array}$ & BioGaia \\
\hline Lactobacillus rhamnosus ATCC 53013 (LGG) & Vifit and others & Valio \\
\hline $\begin{array}{l}\text { Lactobacillus rhamnosus } \mathrm{LB} 21 \\
\text { Lactobacillus salivarius } \mathrm{UCC} 118\end{array}$ & Verum & Norrmejerier \\
\hline Saccharomyces cerevisiae (boulardir) lyo & $\begin{array}{l}\text { DiarSafe, } \\
\text { Ultralevure, etc. }\end{array}$ & $\begin{array}{l}\text { Wren Laboratories, } \\
\text { Biocodex, etc. }\end{array}$ \\
\hline $\begin{array}{l}\text { Tested as mixture: } \\
\text { Lactobacillus acidophilus CL1285 \& L.casei } \\
\text { Lbc80r }\end{array}$ & Bio $\mathrm{K}^{+}$ & Bio $\mathrm{K}+$ International \\
\hline $\begin{array}{l}\text { Tested as mixture: } \\
\text { Lactobacillus rhamnosus GR-1 \& L. reuteri RC-14 } \\
\text { Tested as mixture: }\end{array}$ & FemDophilus & Chr. Hansen \\
\hline $\begin{array}{l}\text { VSL\#3 (mixture of one strain of Streptococcus } \\
\text { thermophilus, four Lactobacillus spp., \& three }\end{array}$ & VSL\#3 & $\begin{array}{l}\text { Sigma-Tau } \\
\text { Pharmaceuticals, Inc. }\end{array}$ \\
\hline $\begin{array}{l}\text { Bifidobacterium spp. strains } \\
\text { Tested as mixture: }\end{array}$ & & \\
\hline $\begin{array}{l}\text { Lactobacillus acidophilus CUL60 \& } \\
\text { Bifidobacterium bifidum CUL } 20 \\
\text { Tested as mixture: }\end{array}$ & & \\
\hline $\begin{array}{l}\text { Lactobacillus helveticus R0052 \& L rhamnosus } \\
\text { R0011 }\end{array}$ & $\begin{array}{l}\text { A'Biotica and } \\
\text { others }\end{array}$ & Institut Rosell \\
\hline $\begin{array}{l}\text { Tested as mixture: } \\
\text { Bacillus clausï strains } \mathrm{O} / \mathrm{C}, \mathrm{NR}, \mathrm{SIN} \text {, and } \mathrm{T}\end{array}$ & Enterogermina & Sanofi-Aventis \\
\hline
\end{tabular}

erate energy in the liver and butyric acid also has an effect to prevent colorectal cancer in the large intestine [37, 42]

\section{Gut microbiota}

Among the digestive organs of humans, microorganisms exist mostly in the large intestine, comprise hundreds of species, and have about 600,000 genes $[2,13,41]$. In recent days, a biopsy was conducted of the feces and the large intestine of humans and determined that there are 9 phyla of microorganisms (Firmicutes, Bacteroidetes, Actinobacteria, Fusobacteria, Proteobacteria, Verrucomicrobia, Cyanobacteria, Spirochaetes, and VadinBE97) [5]. However, as for the dominance ratio of these microorganisms, Firmicutes account for 65\%, Bacteroidetes for $25 \%$, and the remaining $10 \%$ is ascribed to Proteobacteria, 
Actinobacteria, and Fusobacteria in that order $[3,9,15,50]$. Of the microorganisms, Firmicutes is the greatest player in the mouth, the gullet, the small intestine, and the large intestine. In contrast, in the stomach, Actinobacteria is the greatest player, followed by Firmicutes and Proteobacteria. In the gullet, the small intestine, and the large intestine, the dominance ratio of Firmicutes is the highest followed by Bacteroidetes. In the mouth, the dominance ratio of Firmicutes is still high, but unlike in the case of the gullet, small intestine, and large intestine, the dominance ratio of Firmicutes is followed by that of Proteobacteria. Such facts show a very simple aspect, considering the fact that that there are 55 phyla of bacteria in total and 13 phyla of archaea presently known on earth, and considering the microbial diversity of microbial communities in general soil or sea environments. A wide range of heterogeneous soil environments contributes to the expansion of the diversity of microorganisms [54, 56]. In comparison, in environments where the ingredients and the structure of foods are not much different in each region of the intestines, since foods are evenly mixed and digested due to a peristaltic movement of the intestines, a relatively lower diversity of microorganisms is expected [15, 30].

Bacteria in the small intestine has a major effect on immune function since there are many organized lymphoid structures in small-intestinal mucosa (Peyer's patches) and because the epithelium of the small intestine is specialized into cells which involve the uptake and sampling of antigens, and have lymphoid germinal centers where adaptive immune responses are induced. The intestine is the body's most important immune function - related organ, and intestinal mucosa account for about $60 \%$ of a body's immune cells; such an immune system adjusts immune responses to dietary proteins, prevention of food allergies, pathogenic microorganisms, viruses (rotavirus, poliovirus), bacteria (Salmonella, Listeria, Clostridium, etc.), and parasites (Toxoplasma). Probiotics activate local macrophages and increases the antigen presentation of $B$ lymphocytes, inducing immunoglobulin A (IgA) production $[29,40]$

\section{Gut microbiota and obesity}

It is known that microorganisms have a slightly different composition in each human body and will change over time, and each person has a different response to microorganisms. Currently it is reported that changes in these microorganism communities are related to diverse sicknesses like autism
[17], ankylosing spodylitis [51], inflammatory bowel disease [39], obesity [6], and others. Of such sicknesses, obesity has been researched in more detail; a comparison between the ratios of Firmicutes and Bacteroidetes, which account for most intestinal microorganism communities, revealed that an increase in Bacteroidetes is connected to the reduction of body weight. Other research has found that genetically obese mice have a better ability to collect energy from foods than lean mice do. These results suggest that, as for obesity caused by intestinal microorganisms, the causal microbes may be used as a biomarker or a treatment goal for obesity [30]. Obesity is a result of surplus calories that have not been used are accumulated as body fat, when there is an imbalance between the calories absorbed into the body from nutrients and the calories consumed for bio-functions or physical exercise [6]. Firmicutes and Bacteroidetes phyla are predominant intestinal microbiota which account for more than $85 \%$ of intestinal microorganisms and that include some pathogenic microorganisms. Firmicutes is a class which takes the largest portion of intestinal microbiota, comprising about 250 genera such as Lactobacillus, Mycoplasma, Bacillus, Clostridium, and Strpetococcus, the microbe species have diverse physiological characteristics or a different effect in contributing to their host, and comprise many microbes like a well-known useful microbe or lactobacillus and a pathogenic microbe causing strep throat. Of the Bacteroidetes phyla, which include about 20 genera, Bacteroides genus as a single microbe takes the largest portion $[7,9]$. According to a report released by professor Gordon and his team, the ratio of Firmicutes is higher among intestinal microbes, and that of Bacteroidetes is lower in an obese body compared to lean men; when an obese body shows body weight reduction for more than a year, the ratio of Firmicutes and Bacteroidetes becomes gradually similar to that of a lean body [30]. Insoluble polysaccharides (Xylans, manans, pectins, inuline) induce the generation of short-chain fatty acids (SCFA; acetate, propionate, butyrate), which are all decomposed by intestinal microorganisms and finally absorbed in the large intestine via intermediate products such as lactate and succinate (Fig. 2). As for Firmicutes, which inhabits the distal gut, such clostridium communities as Roseburia, E. rectal, Eubacterim halli, and Anaerostips caccae are important microorganisms generating butyrate [28], and acetate generation processes by intestinal microorganisms are another biochemical pathway to explain the relationship between the clostridium communities and obesity [30]. Polysaccharides, 
which have a less complex composition (like soluble starch or fructooligosaccharides) are used by intestinal microorganisms such as Bacteroides and Bifidobacterium, and which generate SCFA via intermediate products (Fig. 1) [47]. SCFA combine with specific Gprotein-coupled receptors (GPR41 and GPR43, also called the free fatty acid receptors FFAR3 and FFAR2, respectively) and promote the nutrient absorption and adipose tissue mass development. When SCFA are combined with GPR41 and activated, gut hormone PYY is discharged. This peptide increases the intestinal transit time and facilitates the absorption of nutriments like glucose [46]. Moreover, some SCFA are combined with GPR43 within fat tissues and inhibit lipolysis and increase PPARy (peroxisome proliferator-activated receptor $\mathrm{\gamma}$ )-related differentiation, the effect of which increases the adiposity. Intestinal microorganisms reduce the intestinal expression of angiopoietin-related protein 4 (ANGPTL4) and increase LPL (lipoprotein lipase)-controlled fatty acid storage in adipose tissues. A rise in the level of blood LPS (lipopolysaccharide) improves the intestinal permeability and increases the gut's permeability by means of the intestinal activation of an intestinal endocannabinoid system. Also, LPS produces serum amyloid A3 protein SAA3) pep- tide in gut and adipose tissues. In obese animals, prebiotics increase the production of glucagon-like peptide (GLP)-1 and GLP-2, lower the intestinal wall's permeability, and inhibit the endocannabinoid system in gut and adipose tissues. In addition, prebiotics blunt the overexpression of GPR43 in adipose tissues and increase lipolysis, reducing the adiposity (Fig. 2) [12].

Microorganisms that generate butyrate are related to obesity-inducing processes, but butyrate itself may be regarded as a metabolite subservient to health [22]. Butyrate supplies more than $70 \%$ of the energy required by enterocyte and contributes to the growth regulation and differentiation of epithelial cells (Fig. 1) [7]. Also, butyrate has an impact on the generation of glucagon-like-peptide 1 (GLP-1), which is connected to anti-inflammatory effects and satiety; unlike butyrate, acetate and propionate generated in lumen move to the liver through a hematocele [11, 22]. Acetate activates cytosolic acetyl S CoA synthetase 2 in liver lipid and promotes the composition of lipid and cholesterol, while an animal experiment found that propionate hinders the action of acetate [55]. In fact, animal experiments show that propionate generated by the fermentation of starch or fructans lowers the cholesterol concentration in liver and blood, and that

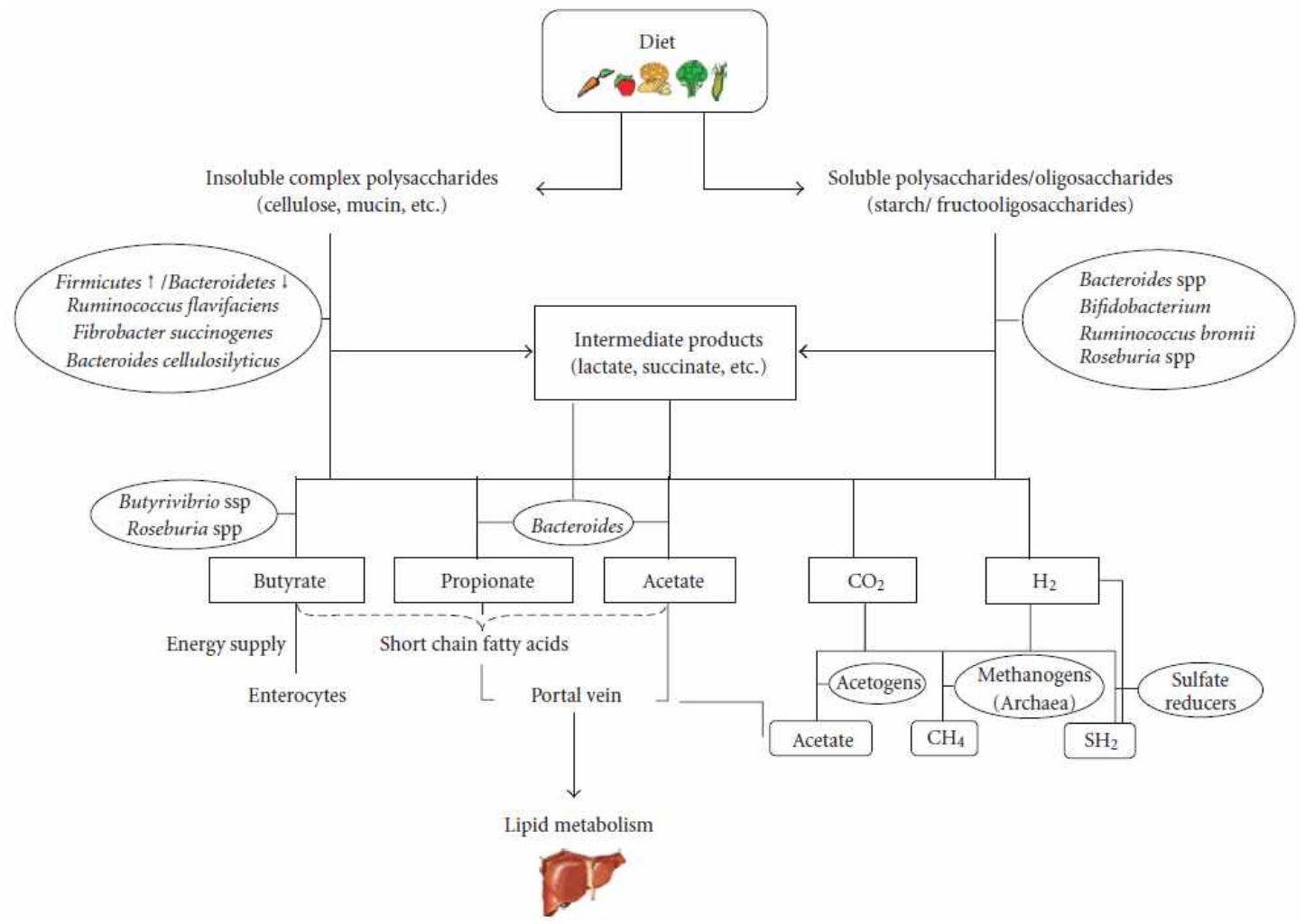

Fig. 1. Schematic diagram of the main metabolic pathways of dietary poly- and oligosaccharides in the gut ecosystem [11]. 


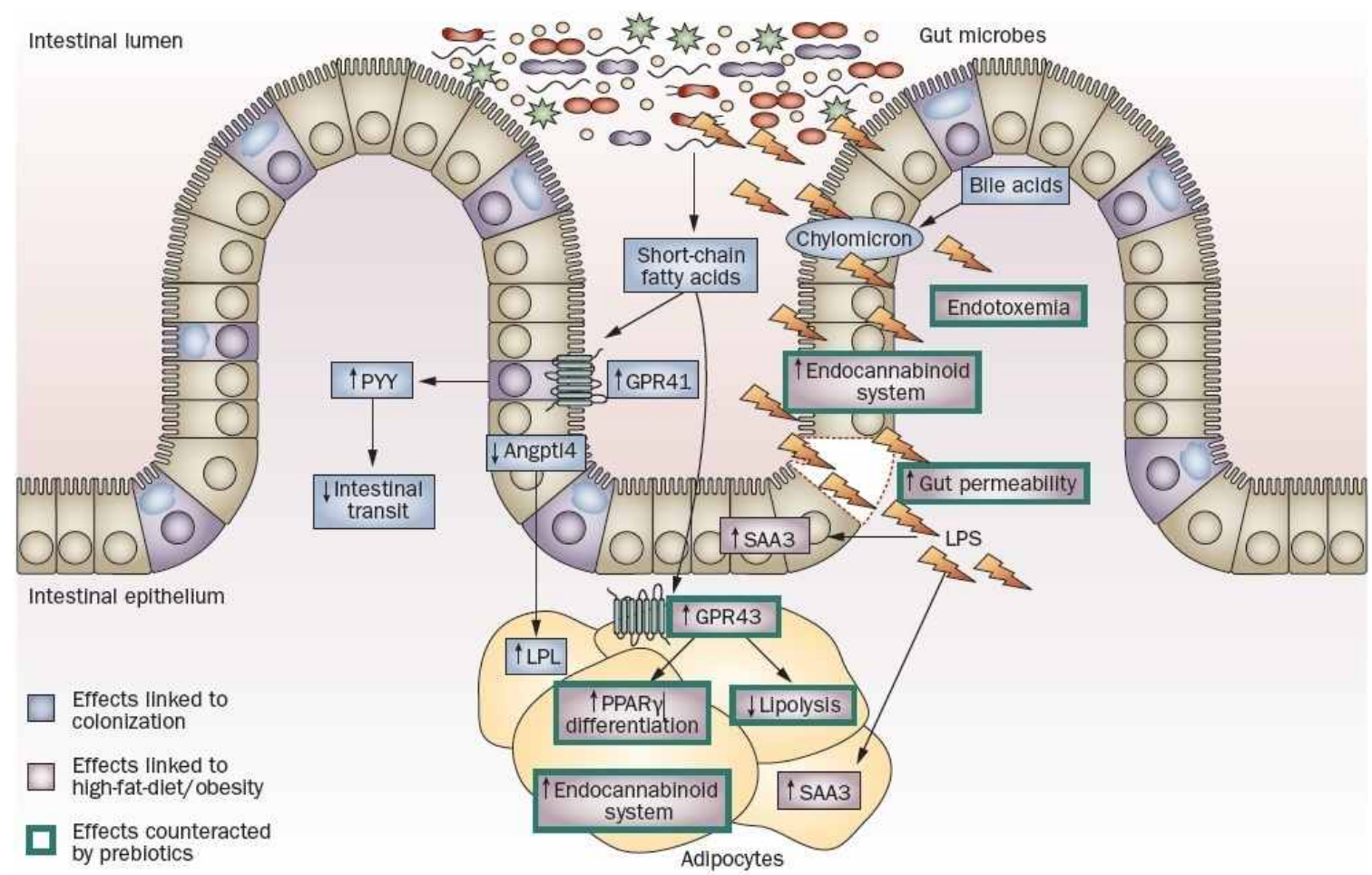

Fig. 2. The host's metabolic responses to changes affecting its gut microbiota, including colonization of the gut in germ-free mice, obesity and high-fat diet, and administration of prebiotics. Abbreviations: ANGPTL4, angiopoietin-related protein 4; GLP, glucagon-like peptide; GPR, G-protein coupled receptor; LPL, lipoprotein lipase; LPS, lipopolysaccharide; PPARr, peroxisome proliferator-activated receptor 8 ; PPY, peptide YY; SAA3, serum amyloid A3 protein [12].

the ratio of acetate/propionate in the portal vein is suggested as a marker to show the effects of dietary ingredients on the metabolism of lipids [10, 31]. Intestinal microorganisms also influence the expression of genes that are related to metabolic functions. When intestinal microorganism microbiota are transplanted into adult germ-free animals in which the generation of new peripheral blood vessels is stopped, the generation of new blood vessels can be observed after microorganism microbiota have settled down, and $B$. thetaiotaomicron raises the absorption rate for monosaccharides or short chain fatty acids and induces the composition of lipid in the liver [25, 55]. As fat composition processes in the liver are activated and shown as an increase in the concentration of insulin and glucose, so intestinal microorganism microbiota settling down in germ-free animals increase acetyl-CoA carboxylase and fatty acid synthase, which involves fatty acid biosynthesis pathways in the liver [4]. Germ-free animals that do not have intestinal microorganisms do not easily become fat, even when they are administered with a type of diet which increases FIAF (fasting induced adipose factor) inhibiting fat accumulation in adipocyte and promoting fat oxidation in muscle, which enhances phosphorylated AMP-activated protein kinase and fatty acid $\beta$-oxidation in skeletal muscle and liver, and which raises the body weight so that fat or glucide content may be high $[1,44]$.

\section{Conclusions}

We are living along with numerous microorganisms. In particular, the number of microorganisms in the large intestine (colon) is about 10 times as many as the total number of cells in the human body, and the genes of the microorganisms number 100 times as many as those in the human body. These microorganisms make up for what we need not evolve by ourselves or what we cannot. Along with them, we are growing to be a complete individual. The effects of such microorganisms as surround us within and without on our health are startlingly great beyond our imagination, of which we are obtaining a greater awareness of as modern science develops. In a word, intestinal microorganisms act like another intestine inside of us. As our knowledge of them is accumulated, there is a good chance we will have to change our methods of keeping healthy in the future. We 
will possibly see a day when we have the ability to prevent or cure various diseases such as obesity or immune system disorders through well-controlled microorganisms; continually observing their structures and functions, checking the conditions of our health, and restoring or transforming them into a desirable form.

\section{Acknowledgement}

This work was supported by the Honam Leading Industry Office through the Leading Industry Development for Economic Region and local industrial technology development project (project no. R0000861), Ministry Knowledge Economy, Republic of Korea.

\section{References}

1. Ackhed, F. B“., Manchester, J. K., Semenkovich, C. F. and Gordon, J. I. 2007. Mechanisms underlying the resistance to diet induced obesity in germ-free mice. Proc Natl Acad Sci USA 104, 979-984.

2. Allen, S. J., Martinez, E. G., Gregorio, G. V. and Dans, L. F. 2010. Probiotics for treating acute infectious diarrhoea. Cochrane Database Syst Rev 11, CD003048.

3. Arumugam, M., Raes, J., Pelletier, E., Paslier, D. L., Yamada, T., Mende, D. R., Fernandes, G. R., Tap, J., Bruls, T., Batto, J. M., Bertalan, M., Borruel, N., Casellas, F., Fernandez, L., Gautier, L., Hansen, T., Hattori, M., Hayashi, T., Kleerebezem, M., Kurokawa, K., Leclerc, M., Levenez, F., Manichanh, C., Bjørn, H., Nielsen, T., Pons, N., Poulain, J., Qin, J., Ponten, T. S., Tims, S., Torrents, D., Ugarte, E., Zoetendal, E.G., Wang, J., Guarner, F., Pedersen, O., Vos, W. M. D., Brunak, S., Doré, J. and Consortium, M. 2011. Enterotypes of the human gut microbiome. Nature 473, 174-180.

4. Bäckhed, F., Ding, H., Wang, T., Hooper, L. V., Koh, G. Y., Nagy, A., Semenkovich, C. F., Gordon, J. I. and Affiliations, A. 2004. The gut microbiota as an environmental factor that regulates fat storage. Proc Natl Acad Sci USA 101, 1571815723.

5. Backhed, F., Ley, R. E., Sonnenburg, J. L., Peterson, D. A. and Gordon, J. I. 2005. Host-bacterial mutualism in the human intestine. Science 307, 1915-1920.

6. Bajzer, M. and Randy, J. S. 2006. Physiology: Obesity and gut flora. Nature 444, 1009-1010.

7. Belenguer, A., Duncan, A. S. H., Calder, G., Holtrop, G., Louos, P., Lobley, G. E. and Flint, H. J. 2006. Two routes of metabolic cross-feeding between Bifidobacterium adolescentis and butyrate-producing anaerobes from the human gut. Appl Environ Microbiol 72, 3593-3599.

8. Brigidi, P., Vitali, B., Swennen, E., Bazzocchi, G. and Matteuzzi, D. 2001. Effects of probiotic administration upon the composition and enzymatic activity of human fecal mi- crobiota in patients with irritable bowel syndrome or functional diarrhea. Res Microbial 152, 735-741.

9. Dave, M., Peter, D., Middhac, S. and Rioux, K. P. 2012. The human gut microbiome: current knowledge, challenges, and future directions. Transl Res 160, 246-257.

10. Delzenne, N. M. and Kok, N. 2001. Effects of fructans-type prebiotics on lipid metabolism. Am J Clin Nutr 73, 456-458.

11. Delzenne, N. M., Cani, P. D. and Neyrinck, A. M. 2007. Modulation of glucagon-like peptide 1 and energy metabolism by inulin and oligofructose: experimental data. J Nutr 137, 2547-2551.

12. Delzenne, N. M., Neyrinck, M. A., Bäckhed, F. and Cani, P. D. 2011. Targeting gut microbiota in obesity: effects of prebiotics and probiotics. Nat Rev Endocrinol 7, 639-646.

13. Deshpande, G., Rao, S., Patole, S. and Bulsara, M. 2010. Updated meta-analysis of probiotics for preventing necrotizing enterocolitis in preterm neonates. Pediatrics 125, 921-930.

14. DiBaise, J. K., Zhang, H., Crowell, M. D., Brown, R. K., Decker, G. A. and Rittmann, B. E. 2008. Gut microbiota and its possible relationship with obesity. Mayo Clin Proc 83, 460-469.

15. Eckburg, P. E., Bernstein, C. N., Purdom, E., Dethlefsen, L., Sargent, M., Gill, S. R., Nelson, K. E. and Relman, D. A. 2005. Diversity of the human intestinal microbial flora. Science 308, 1635-1638.

16. Filippo, D. C., Cavalieria, D., Paolab, M. D., Ramazzottic, M., Poulletd, J. B., Massartd, S., Collinib, S., Pieraccinie, G. and Lionettib, P. 2010. Impact of diet in shaping gut microbiota revealed by a comparative study in children from Europe and rural Africa. Proc Natl Acad Sci USA 107, 1469114696.

17. Finegold, S., Molitoris, M. D., Song, Y., Liu, C., Vaisanen, M. L., Bolte, E., McTeague, M., Sandler, R., Wexler, H., Marlowe, E. M., Collins, M. D., Lawson, P. A., Summanen, P., Baysallar, M., Tomzynski, T. J., Read, E., Johnson, E., Rolfe, R., Nasir, P., Shah, H., Haake, D. A., Manning, P. and Kaul, A. 2002. Gastrointestinal microflora studies in late-onset autism. Clin Infect Dis 35, 6-16.

18. Floch, M. H., Madsen, K. K. and Jenkins, D. J. 2006. Recommendations for probiotic use. J Clin Gastroenterol 40, 275-278.

19. Gibson, G. R., Probert, H. M., Rastall, R. A. and Roberfroid, M. R. 2004. Dietary modulation of the human colonic microbiota: updating the concept of prebiotics. Nutr $\operatorname{Res} \operatorname{Rev} 17$, 259-275.

20. Guarner, F., Khan, A. G., Garisch, J., Eliakim, E., Gangl, A. Thomson, A., Krabshuis, J., Lemair, T., outside experts, I., Kaufmann, P., de Paula, J. A., Fedorak, R., Shanahan, F., Sanders, M. E., zajewska, H., Ramakrishna, B. S. and Karakan, T. 2011. Probiotics and prebiotics. World Gastroenterology Organisation.

21. Haarman, M. and Knol, J. 2005. Quantitative real-time PCR assays to identify and quantify fecal Bifidobacterium species in infants receiving a prebiotic infant formula. Appl Environ Microbiol 71, 2318-2324.

22. Hamer, H. M., Jonkers, D., Venema, K., Vanhoutvin, S., 
Troost, F. J. and Brummer, R. J. 2008. Review article: the role of butyrate on colonic function. Aliment Pharmacol Ther 27, 104-119.

23. Harmsen, H. J., Raangs, G. C., Franks, A. H., WildeboerVeloo, A. C. M. and Welling, G. W. 2002. The effect of the probiotic inulin and the probiotic Bifidobacterium longum on the fecal microflora of healthy volunteers measured by FISH and DGGE. Microbiol Ecol Health Dis 14, 211-219.

24. Holzapfel, W. H., Haberer, P., Snel, J., Schillinger, U. and Veld, H. I. 1998. Overview of gut flora and probiotics. $K$. Food Microbiol 41, 85-101.

25. Hooper, L. V., Wong, M. H., Thelin, A., Hansson, L., Falk, P. G. and Gordon, J. I. 2001. Molecular analysis of commensal host microbial relationships in the intestine. Science 291, 881-884

26. Klaenhammer, T., Altermann, E. and Arigoni, F. 2002. Discovering lactic acid bacteria by genomics. Antonie Van Leeuwenhoek 82, 29-58.

27. Kuehl, C., Wood, H., Marsh, T. L., Schmidt, T. M. and Young, V. B. 2005. Colonization of the cecal mucosa by Helicobacter hepaticus impacts the diversity of the indigenous microbiota. Infect Immun 73, 6952-6961.

28. Leitch, E. C. M, Walker, A. W., Duncan, S. H., Holtrop, G. and Flint, H. J. 2007. Selective colonization of insoluble substrates by human faecal bacteria. Environ Microbiol 9, 667-679.

29. Lenoir-Wijnkoop, I., Sanders, M. E., Cabana, M. D., Corthier, G., Rayes, N., Sherman, P. M., Timmerman, H. M., Vaneechoutte, M., Loo, J. V. and Wolvers, D. A. W. 2007. Probiotic and prebiotic influence beyond the intestinal tract. Nutr Rev 65, 469-489.

30. Ley, R., Peter, E., Turnbaugh, J., Klein, S. and Gordon, J. 2006. Microbial ecology: human gut microbes associated with obesity. Nature 444, 1022-1023.

31. Lopez, H. W., Levrat-Verny, M. A., Coudray, C., Besson, C., Krespine, V., Messager, A., Demigné, C. and Rémésy, C. 2001. Class 2 resistant starches lower plasma and liver lipids and improve mineral retention in rats. J Nutr 131, 1283-1289.

32. Mallon, P., McKay, D., Kirk, S. and Gardiner, K. 2007. Probiotics for induction of remission in ulcerative colitis. Cochrane Database Syst Rev 4, CD005573.

33. Martin, F., Wang, E. Y., Dumas, M., Yap, I. K. S., Cloarec, O., Bergonzelli, G. E., Theulaz, I., Kochhar, S., Holmes, E., Lindon, J. C., Collinsand, S. M. and Nicholson, J. K. 2006. Transgenomic metabolic interactions in a mouse disease model: Interactions of Trichinella spiralis infection with dietary Lactobacillus paracasei supplementation. J Proteome Res 5, 2185-2193

34. Martína, R., Langaa, S., Reviriegoa, C., Jiméneza, E., Marína, M. L., Olivaresb, M., Bozab, J., Jiménezb, J., Fernándeza, L., Xausb, J. and Rodrígueza, J. M. 2004. The commensal microflora of human milk: new perspectives for food bacteriotherapy and probiotics. Trends Food Sci Technol 15, 121-127.

35. Mättö, J., Malinen, E., Suihko, M. L., Alander, M., Palva,
A. and Saarela, M. 2004. Genetic heterogeneity and functional properties of intestinal Bifidobacteria. J Appl Microbiol 97, 459-470.

36. Morrison, D. J., Mackay, W. G., Edwards, C. A., Preston, T., Dodson, B. and Weaver, L. T. 2006. Butyrate production from oligofructose fermentation by the human faecal flora: what is the contribution of extracellular acetate and lactate? J Nutr 96, 570-577.

37. Okazaki, Y., Sitanggang, N. V., Sato, S., Ohnishi, N., Inoue, J., Iguchi, T., Watanabe, T., Tomotake, H., Harada, K. and Kato, N. 2013. Burdock fermented by Aspergillus awamori elevates cecal Bifidobacterium, and reduces fecal deoxycholic acid and adipose tissue weight in rats fed a high-fat diet. Biosci Biotechnol Biochem 77, 53-57.

38. O'Mahony, L., McCarthy, J., Kelly, P., Hurley, G., Luo, F., Chen, K., O'Sullivan, G. C., Kiely, B., Collins, J. K., Shanahan, F. and Quigley, E. M. M. 2005. Lactobacillus and Bifidobacterium in irritable bowel syndrome: symptom responses and relationship to cytokine profiles. Gastroenterdogy $128,541-551$

39. Osborn, D. A. and Sinn, J. K. 2007. Probiotics in infants for prevention of allergic disease and food hypersensitivity. Cochrane Database Syst Rev 4, CD006475.

40. Ott, S., Musfeldt, M., Wenderoth, D. F., Hampe, J., Brant, O., Fölsch, U. R., Timmis, K. N. and Schreiber, S. 2004. Reduction in diversity of the colonic mucosa associated bacterial microflora in patients with active inflammatory bowel disease. Gut 53, 685-693

41. Qin, J, Raes, R., Arumugam, J., Burgdorf, M. K. S., Manichanh, C., Nielsen, T., Pons, N., Levenez, F., Yamada, T., Mende, D., Li, J., Xu, J., Li, S., Li, D., Cao, J., Wang, B., Liang, H., Zheng, H., Xie, Y., Tap, J., Lepage, P., Bertalan, M., Batto, J., Hansen, T., Paslier, D., Linneberg, A., Nielsen, H. B., Pelletier, E., Renault, P., Ponten, T., Turner, K., Zhu, H., Yu, C., Li, S., Jian, M., Zhou, Y., Li, Y., Zhang, X., Li, S., Qin, N., Yang, H., Wang, J., Brunak, S., Doré, J., Guarner, F., Kristiansen, K., Pedersen, O., Parkhill, J., Weissenbach, J., Consortium, M., Bork, P., Ehrlich, S. and Wang, J. 2010. A human gut microbial gene catalogue established by metagenomic sequencing. Nature 464, 59-65.

42. Ramnani, P., Gaudier, E., Bingham, M., van Bruggen, P., Tuoh, K. M. and Gibson, G. R. 2010. Prebiotic effect of fruit and vegetable shots containing Jerusalem artichoke inulin: a human intervention study. J Nutr 104, 233-240.

43. Reid, G., Jass, J., Sebulsky, M. T. and McCormick, J. K. 2003. Potential uses of probiotics in clinical practice. Clin Microbiol $16,658-672$.

44. Sakakibara, S., Yamauchi, T., Oshima, Y., Tsukamoto, Y. and Kadowaki, T. 2006. Acetic acid activates hepatic AMPK and reduces hyperglycemia in diabetic KK-A(y) mice. Biochem Biophyl Res Commun 344, 597-604.

45. Salminen, S., Bouley, C., Boutron-Ruault, M. C., Cummings, J. H., Franck, A., Gibson, G. R., Isolauri, E., Moreau, M. C., Roberfroid, M. and Rowland, I. 1998. Functional food science and gastrointestinal physiologyand function. J Nutr 80 , 147-171. 
46. Samuel, B. S., Shaito, A., Motoike, T., Rey, F. E., Backhed, F., Manchester, J. K., Hammer, R. E., Williams, S. C., Crowley, J., Yanagisawa, M. and Gordon, J. I. 2008. Effects of the gut microbiota on host adiposity are modulated by the short-chain fatty-acid binding $G$ protein-coupled receptor, Gpr41. Proc Natl Acad Sci USA 105, 16767-16772.

47. Sanz, Y., Santacruz, A. and De Palma, G. 2008. Insights into the roles of gut microbes in obesity. Interdiscip Perspect Infect Dis 2008, 829101.

48. Shanahan, F. 2010. Probiotics in perspective. Gastroenterology 139, 1808-1812.

49. Sprunt, K. and Leidy, G. 1988. The use of bacterial interference to prevent infection. Can J Microbiol 34, 332-338

50. Stappenbeck, T. S., Hooper, L. V. and Gordon, J. I. 2002. Developmental regulation of intestinal angiogenesis by indigenous microbes via Paneth cells. Proc Natl Acad Sci USA 99, 15451-15455.

51. Stebbings, S., Munro, K., Simon, M. A., Tannock, G., Highton, J., Harmsen, H., Welling, G., Seksik, P., Dore, J., Grame, G. and Tilsala-Timisjarvi, A. 2002. Comparison of the faecal microflora of patients with ankylosing spondylitis and controls using molecular methods of analysis. Rheumatology 41, 139513401.

52. Tannock, G. W. 1997. Probiotic properties of lactic-acid bacteria: plenty of scope for fundamental R\&D. Trends Biotechnol 15, 270-274

53. Tannok, G., Munro, K., Harmsen, H. J. M., Welling, G. W., Smart, J. and Gopal, P. K. 2000. Analysis of the fecal microflora of human subjects consuming a probiotic product contacting Lactobacilus rhamnosus DR20. Appl Enviton Microbiol 66, 2578-2588.

54. Turnbaugh, P. J., Ley, R. E., Hamady, M., Fraser-Liggett, C. M., Knight, E. and Gordon, J. I. 2007. The human microbiome project. Nature 449, 804-810.

55. Wolever, T. M. S., Spadafora, P. J., Cunnane, S. C. and Pencharz, P. B. 1995. Propionate inhibits incorporation of colonic $[1,2-13 C]$ acetate into plasma lipids in humans. Am $J$ Clin Nutr 61, 1241-1247.

56. Zhou, J., Xia, B., Treves, S. D., Wu, L. Y., Marsh, T. L., O'Neill, R. V., Palumbo, A. V. and Tiedje, J. M. 2002. Spatial and resource factors influencing high microbial diversity in soil. Appl Environ Microbiol 68, 326-334.

\section{초록 : 대장에서 prebiotics와 probiotics 역할에 대한 조명}

안수진 ${ }^{1} \cdot$ 김재영 $^{1} \cdot$ 최인순 $^{2} \cdot$ 조광근 $^{1} \star$

( ${ }^{1}$ 경남과학기술대학교 동물소재공학과, ${ }^{2}$ 신라대학교 생물학과)

현재까지 밝혀진 사실에 의하면 지구상에는 55개 phylum의 bacteria와 13개 phylum의 archaea가 존재하여 총 68개 phylum 있으며, 대장에는 9개 phylum의 미생물이 존재하여 일반 토양환경이나 해양환경에 비하여 상대적 으로 낮은 미생물 다양성을 가지고 있다. 장내 미생물의 다양성은 Host의 고유특성(genetic background, sex, age, immune system, gut motility)과 식이(nondigestible carbohydrates fat, prebiotics or probiotics), 항생제 섭취 등 으로 인하여 영향 받으며, 이러한 영향이 에너지 저장 과정과 유전자 발현을 영향을 주고 나아가 비만과 같은 대사질환에 영향을 미친다. Probiotics는 숙주의 장내 균총을 개선하여 건강에 유익함을 줄 수 있는 살아있는 미생 물을 말하며, 주로 lactic acid bacteria들이 이용되어 왔다. 최근 probiotics를 이용한 설사나 과민성대장증후군 등 과 같은 질병 치료를 위하여 bacteriotherapy가 활용되고 있다. Prebiotics는 장내 미생물을 선택적으로 조절할 수 있는 식품 성분으로 inulin, fructo-oligosaccharides, galacto-oligosaccharides, lactulose 등이 이용되고 있으며, 최 근에는 비만, 항암과 관련하여 대장 내 식이섬유소의 이용과 단쇄지방산(short-chain fatty acids) 생산에 대한 관 심이 집중되고 있다. 다양한 nondigestible carbohydrates와 prebiotics, probiotics에 의해서 조절되는 대장 내 특정 미생물 종을 규명하고, 이들 미생물 종이 생산하는 단쇄지방산과 같은 대사산물들과 질병과의 연관성 규명하는 대장 미생물 연구가 더욱 필요하다. 